\title{
Ordovician volcanic and hypabyssal rocks in the central and southern Miramichi Highlands: their tectonic setting and relationship to contemporary volcanic rocks in northern New Brunswick
}

\author{
J.A. Winchester \\ University of Keele, Keele, Staffordshire, England ST5 5BG \\ C.R. van Staal \\ Geological Survey of Canada, 601 Booth Street, Ottawa, Ontario K1A OE8, Canada \\ and \\ L.R. Fyffe \\ Department of Natural Resources and Energy, P.O. Box 6000, \\ Fredericton, New Brunswick E3B 5H1, Canada
}

Date Received August 8, 1991

Date Accepted November 25, 1991

\begin{abstract}
New analyses of mafic igneous rocks from the central Miramichi Highlands have led us to modify the interpretation of its tectonic setting. New samples have been obtained from the Bamford Brook and Trousers Lake areas of New Brunswick, and the Danforth area in Maine. All subalkalic mafic rocks, including the Trousers Lake striped amphibolites, are associated with a thick sequence of metasedimentary rocks and all are continental tholeiites, analogous to tholeiitic suites in the Tetagouche Group of the northern Miramichi Highlands. The presence of alkalic basalt and comendite in this area supports this correlation. In the southern Miramichi Highlands of Maine, silicic and intermediate volcanic rocks form part of the Woodstock-Meductic arc-related volcanic suite.
\end{abstract}

De nouvelles analyses de roches ignées mafiques provenant du centre des hautes-terres de la Miramichi nous ont conduit à modifier l'interprétation de leur environnement tectonique. De nouveaux échantillons ont été recueillis dans les régions du ruisseau Bamford et du lac Trousers au Nouveau-Brunswick, et dans la région de Danforth au Maine. Toutes les roches mafiques subalcalines, incluant les amphibolites rubannées du lac Trousers, sont associées avec une séquence épaisse de roches métasédimentaires et sont toutes des tholéiites continentales, similaires aux suites tholéiitiques appartenant au Groupe de Tétagouche du nord des hautes-terres de la Miramichi. La présence de basaltes alcalins et de comendites dans cette région appuie cette corrélation. Dans le sud des hautes-terres de la Miramichi au Maine, les volcanites siliceuses et intermédiaires constituent une partie de la suite volcanique d'arc de WoodstockMeductic.

[Traduit par le journal]

\section{Introduction and Geological Setting}

In a recent study Fyffe $e t$ al. (1988) described striped and unstriped amphibolites from the Trousers Lake area of the central Miramichi Highlands of New Brunswick (Fig. 1). The distinction between striped and unstriped amphibolite was originally based on their different field appearance: striped amphibolites possess a characteristic compositional banding, whereas the unstriped amphibolites tend to be internally homogeneous. Analysis revealed that the two suites of amphibolite were compositionally distinct. Both amphibolite suites correlate chemically with some of the low-grade basalts of the Middle Ordovician Tetagouche Group exposed elsewhere in the Miramichi Highlands, although the striped amphibolites, which were previously considered to form part of a Precambrian basement inlier (Rast et al., 1976; Fyffe and Pronk, 1985), were thought in part to show arc affinities.

This paper reports the results of analyses of additional samples of amphibolites from the Trousers Lake area, as well as samples of volcanic rocks collected in the Bamford Brook and Sevogle areas in the central Miramichi Highlands and the Danforth area of Maine (Fig. 1). These analyses are compared with the previous results of Fyffe et al. (1988), arc-type volcanic rocks from the Woodstock-Meductic suite in the southern Miramichi Highlands (Dostal, 1990), and volcanic rocks from the Tetagouche Group in the Bathurst area in the northern Miramichi Highlands (van Staal et al., 1991). The comparisons show that metabasalts in the central Miramichi Highlands can be correlated with those of the northern Miramichi Highlands (Table 1) and that, although arc tholeiites are probably not present in the central Miramichi Highlands, the arc affinities of the Woodstock-Meductic volcanic suite are confirmed.

The geology of the areas sampled was described by Fyffe et al. (1988) and Irrinki (1980). The sedimentary rocks, comprising lithic wackes and grey and red cherty slates 


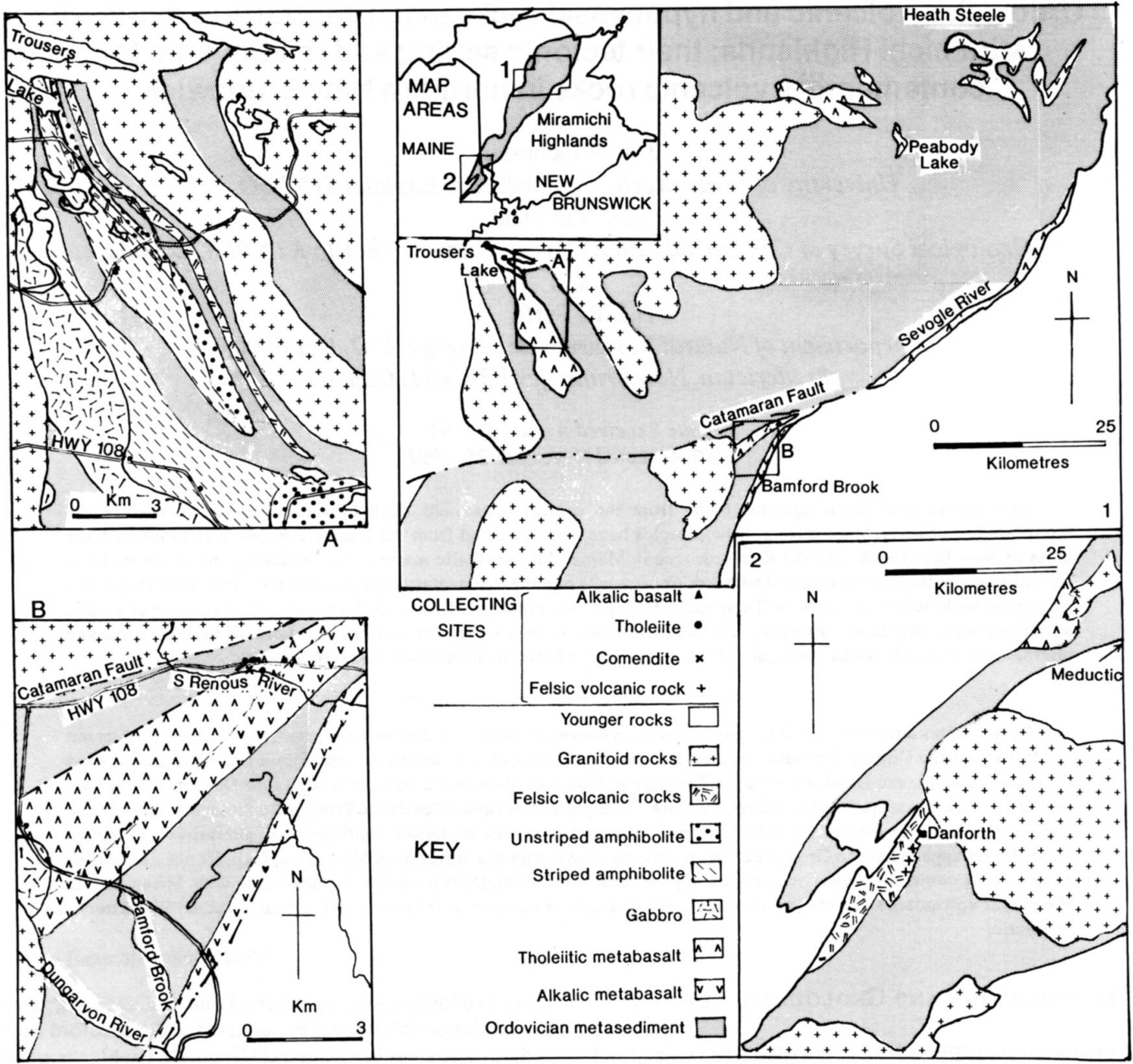

Fig. 1. Location map showing the areas of outcrop of (1) the metavolcanic suites in the CMH, and (2) the southwestern extremity of the Miramichi Highlands in Maine, covering the area where felsic volcanic rocks were collected south of Danforth. Detailed geological maps depicting the Trousers Lake area (A) and the Bamford Brook area (B) are adapted from Fyffe et al. (1988).

associated with the low-grade metavolcanic rocks in the Bamford Brook area of the eastern central Miramichi Highlands, are typical of the Tetagouche Group (Fyffe, 1982). By contrast, the amphibolite-facies psammites and pelites of the western central Miramichi Highlands were included in the Trousers Lake metamorphic suite by Fyffe et al. (1988), as their relationship to the Tetagouche Group was not known.

\section{Geochemical Characteristics of the Volcanic Rocks}

New analyses of rocks from the Trousers Lake and Bamford Brook areas are comparable with those previously obtained in the same areas by Fyffe et al. (1988), thus revealing no significant differences between analyses performed at the different laboratories. Because metamorphism in the Miramichi Highlands ranges from greenschist to amphibolite facies, some chemical change in the various rock suites is probable, particularly with respect to light ion lithophile elements (LILE). We have therefore tended to rely preferentially on the relatively immobile high field strength elements (HFSE) in both classification and tectonic setting determination. $\mathrm{Zr} / \mathrm{Y}$ and $\mathrm{Nb} / \mathrm{Y}$ ratios tend to change little during high-level mafic differentiation and have mainly been used to distinguish the various basaltic suites (Fig. 2a,b).

In the Bamford Brook area new analyses of mafic vol- 
Table 1. New analyses from the central Miramichi Highlands

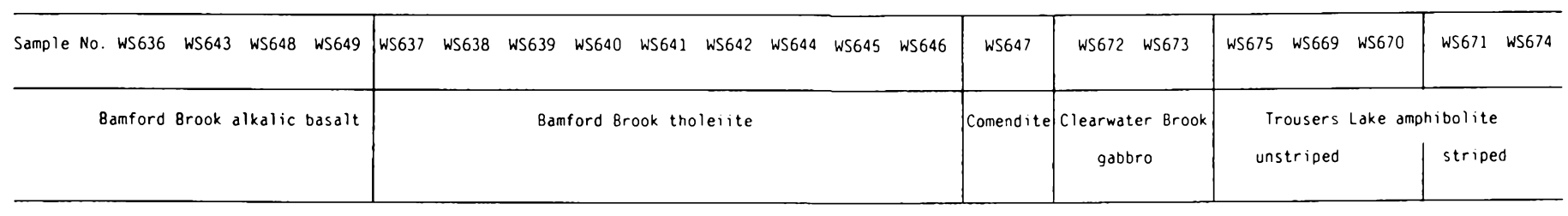

$\begin{array}{llllllllllllll}\mathrm{SiO}_{2} & 48.19 & 49.98 & 45.06 & 46.55 & 52.17 & 47.85 & 49.28 & 47.30 & 48.27 & 46.76 & 47.37 & 48.80 & 49.23\end{array}$

$\begin{array}{lllllllllllllll}\mathrm{TiO}_{2} & 3.62 & 2.91 & 2.62 & 2.80 & 1.10 & 2.13 & 2.06 & 2.73 & 2.43 & 1.50 & 1.47 & 1.57 & 2.08\end{array}$

$\begin{array}{llllllllllllll}\mathrm{Al}_{2} \mathrm{O}_{3} & 14.15 & 12.41 & 16.70 & 16.55 & 15.60 & 15.25 & 14.67 & 15.01 & 14.50 & 15.13 & 16.15 & 16.08 & 14.75\end{array}$

$\begin{array}{lllllllllllllll}\mathrm{Fe}_{2} \mathrm{O}_{3} & 2.19 & 3.19 & 2.85 & 2.47 & 1.61 & 1.92 & 1.99 & 5.59 & 7.23 & 2.31 & 2.71 & 2.47 & 2.91 & 0.55\end{array}$

$\begin{array}{llllllllllllllll}\mathrm{FeO} & 9.72 & 7.95 & 8.37 & 8.18 & 8.53 & 8.28 & 8.08 & 5.06 & 3.61 & 6.51 & 6.41 & 6.63 & 7.11 & 2.14\end{array}$

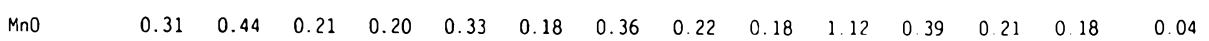

$\begin{array}{lllllllllllllll}\mathrm{MgO} & 5.33 & 5.85 & 5.88 & 5.92 & 7.58 & 8.81 & 8.18 & 5.85 & 3.92 & 8.11 & 8.45 & 6.66 & 7.14 & 0.23\end{array}$

$\begin{array}{llllllllllllllll}\mathrm{CaO} & 9.91 & 6.33 & 10.17 & 8.90 & 7.63 & 10.74 & 9.16 & 5.75 & 7.36 & 9.59 & 8.55 & 8.78 & 7.17 & 0.96\end{array}$

$\begin{array}{lllllllllllllll}\mathrm{Na}_{2} \mathrm{O} & 4.53 & 3.48 & 2.90 & 3.10 & 4.37 & 2.60 & 3.52 & 6.06 & 6.64 & 1.99 & 3.12 & 4.50 & 4.71 & 3.53\end{array}$

$\begin{array}{lllllllllllllll}\mathrm{K}_{2} \mathrm{O} & 0.37 & 0.29 & 1.27 & 1.55 & 0.07 & 0.43 & 0.64 & 0.24 & 0.43 & 2.09 & 1.21 & 0.32 & 0.65 & 1.82\end{array}$

$\begin{array}{llllllllllllllll}\mathrm{P}_{2} \mathrm{O}_{5} & 0.57 & 1.37 & 0.31 & 0.35 & 0.10 & 0.27 & 0.26 & 0.34 & 0.27 & 0.17 & 0.16 & 0.16 & 0.27 & 0.04\end{array}$

$\begin{array}{llllllllllllllll}\mathrm{H}_{2} \mathrm{O} & 0.15 & 5.07 & 4.04 & 3.24 & 0.36 & 0.36 & 0.88 & 4.98 & 5.91 & 3.99 & 4.53 & 3.61 & 3.65 & 1.29\end{array}$

$5 \quad \begin{array}{lllllllllllllll}5 & 0.03 & 0.04 & 0.07 & 0.03 & 0.01 & 0.02 & 0.01 & 0.01 & 0.01 & 0.01 & 0.01 & 0.02 & 0.01 & 0.02\end{array}$

Total $\begin{array}{lllllll}50.89 & 55.01 & 55.42 & 55.11 & 49.00 & 47.96 & 49.87\end{array}$

$\begin{array}{lllllll}1.66 & 1.56 & 1.35 & 1.72 & 1.54 & 1.71 & 1.06\end{array}$

$\begin{array}{llllllll}16.38 & 16.14 & 16.59 & 16.21 & 15.95 & 14.15 & 15.77\end{array}$

$\begin{array}{lllllll}1.96 & 1.90 & 1.65 & 1.86 & 1.79 & 4.66 & 3.30\end{array}$

$\begin{array}{llllllll}6.22 & 6.17 & 8.93 & 6.27 & 8.14 & 7.53 & 1.02\end{array}$

$\begin{array}{llllllll}0.15 & 0.14 & 0.16 & 0.14 & 0.17 & 0.18 & 0.17\end{array}$

$\begin{array}{llllllll}6.32 & 5.36 & 5.98 & 4.60 & 7.76 & 8.46 & 8.52\end{array}$

$\begin{array}{llllllll}9.82 & 8.29 & 0.42 & 7.71 & 10.23 & 11.27 & 10.96\end{array}$

$\begin{array}{lllllll}4.10 & 3.34 & 4.68 & 3.58 & 2.42 & 2.78 & 2.90\end{array}$

$\begin{array}{llllllll}0.77 & 0.84 & 0.02 & 1.41 & 1.10 & 0.33 & -0.10\end{array}$

$\begin{array}{llllllll}0.32 & 0.28 & 0.14 & 0.32 & 0.21 & 0.15 & 0.09\end{array}$

$\begin{array}{llllllll}1.16 & 1.73 & 4.62 & 1.11 & 1.62 & 1.28 & 1.53\end{array}$

$\begin{array}{lllllll}0.01 & 0.01 & 0.01 & 0.02 & 0.03 & 0.02 & 0.03\end{array}$

$\begin{array}{llllll}99.76 & 100.77 & 99.97 \quad 100.06 & 99.96 \quad 100.48 & 100.32\end{array}$

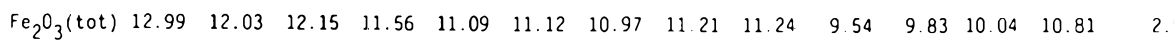

$\begin{array}{lllllll}8.87 & 8.76 & 11.57 & 8.83 & 10.83 & 13.02 & 9.99\end{array}$

рpm

\begin{tabular}{|c|c|c|c|c|c|c|c|c|c|c|c|c|c|c|c|c|c|c|c|c|c|}
\hline$B a$ & 61 & 258 & 122 & 127 & 26 & 183 & 193 & 166 & 340 & 1190 & 742 & 613 & 178 & 692 & 133 & 215 & 45 & 280 & 133 & 39 & 13 \\
\hline $\mathrm{Cl}$ & 187 & 148 & 137 & 119 & 163 & 85 & 154 & 135 & 123 & 106 & 121 & 141 & 117 & 149 & 316 & 207 & 122 & 313 & 160 & 119 & 106 \\
\hline $\mathrm{Cr}$ & 13 & 0 & 40 & 64 & 291 & 481 & 272 & 506 & 494 & 882 & 637 & 398 & 406 & 20 & 145 & 127 & 0 & 104 & 328 & 390 & 358 \\
\hline $\mathrm{Cu}$ & 22 & 22 & 43 & 46 & 70 & 62 & 61 & 37 & 52 & 62 & 55 & 60 & 36 & 0 & 16 & 18 & 92 & 41 & 40 & 68 & 75 \\
\hline Ga & 22 & 21 & 23 & 22 & 12 & 20 & 17 & 15 & 17 & 17 & 16 & 16 & 14 & 32 & 18 & 19 & 15 & 19 & 20 & 19 & 15 \\
\hline No & 27 & 49 & 23 & 22 & 5 & 19 & 23 & 18 & 17 & 13 & 13 & 11 & 15 & 371 & 11 & 10 & 10 & 22 & 12 & 6 & 4 \\
\hline $\mathrm{Ni}$ & 29 & 14 & 27 & 32 & 87 & 184 & 79 & 179 & 189 & 338 & 231 & 154 & 135 & 9 & 40 & 34 & 54 & 23 & 58 & 135 & 105 \\
\hline $\mathrm{Pb}$ & 13 & 9 & 11 & 8 & 9 & 9 & 9 & 11 & 13 & 7 & 10 & 7 & 9 & 25 & 7 & 6 & 1 & 6 & 6 & 7 & 4 \\
\hline$R D$ & 4 & 5 & 10 & 15 & 2 & 13 & 32 & 5 & 6 & 60 & 31 & 5 & 18 & 40 & 27 & 24 & 4 & 42 & 39 & 4 & 3 \\
\hline Sr & 316 & 331 & 361 & 403 & 194 & 210 & 242 & 78 & 201 & 117 & 167 & 242 & 197 & 41 & 429 & 379 & 19 & 321 & 261 & 95 & 97 \\
\hline Th & 1 & 3 & 1 & 0 & 0 & 1 & 0 & 4 & 1 & 1 & 0 & 0 & 1 & 66 & 5 & 7 & 11 & 8 & 1 & 1 & 2 \\
\hline v & 411 & 246 & 345 & 346 & 243 & 329 & 375 & 420 & 381 & 278 & 298 & 326 & 335 & 9 & 255 & 226 & 364 & 237 & 258 & 341 & 257 \\
\hline$Y$ & 43 & 46 & 29 & 32 & 24 & 40 & 42 & 50 & 45 & 29 & 28 & 34 & 42 & 292 & 34 & 31 & 32 & 30 & 26 & 43 & 26 \\
\hline $2 n$ & 110 & 108 & 88 & 93 & 54 & 92 & 82 & 99 & 88 & 81 & 88 & 86 & 97 & 86 & 58 & 63 & 115 & 75 & 81 & 87 & 78 \\
\hline $2 r$ & 282 & 277 & 218 & 215 & 68 & 155 & 135 & 199 & 187 & 77 & 78 & 81 & 153 & 2851 & 164 & 158 & 164 & 111 & 111 & 102 & 65 \\
\hline
\end{tabular}

Rare-Earth Elements

\begin{tabular}{|c|c|c|c|c|c|c|c|c|c|c|c|c|c|c|c|c|c|c|c|c|c|}
\hline La & 15 & 41 & 9 & 6 & 0 & 2 & 4 & 1 & 4 & 2 & 0 & 0 & 2 & 278 & 10 & 10 & 10 & 18 & 5 & 0 & 0 \\
\hline $\mathrm{Ce}$ & 63 & .132 & 47 & 53 & 25 & 12 & 26 & 60 & 21 & 12 & 8 & 8 & 25 & 733 & 41 & 68 & 48 & 53 & 29 & 0 & 2 \\
\hline $\mathrm{Nd}$ & 30 & 66 & 31 & 26 & 28 & 19 & 21 & 44 & 16 & 14 & 21 & 11 & 17 & 265 & 21 & 33 & 25 & 33 & 24 & 13 & 8 \\
\hline
\end{tabular}

Analyses were performed at Keele University, using an ARL $8420 x$-ray fluorescence spectrometer.

Ferrous iron was determined using potassium dichromate as titrant and diphenylamine sulphonate as indicator.

canic rocks include both tholeiitic and alkalic basalts (Table 1). The HFSE and $\mathrm{Cr}$ contents of the analysed basalts vary significantly (Table 1). The tholeiitic basalts are characteristically $\mathrm{Cr}$-rich and chemically resemble the three Forty Mile Brook tholeiites in the southernmost part of the northern
Miramichi Highlands east of Heath Steele Mines (Fig. 1, Tables $1,2,3)$. They fall within the subalkalic basalt field on a $\mathrm{Zr} / \mathrm{TiO}{ }_{2}-\mathrm{Nb} / \mathrm{Y}$ diagram (Fig. 2a; Winchester and Floyd, 1977) and are confined to the western belt of mafic volcanic rocks in the area (Fig. 1). The alkalic basalts are $\mathrm{Cr}$-poor and 
A
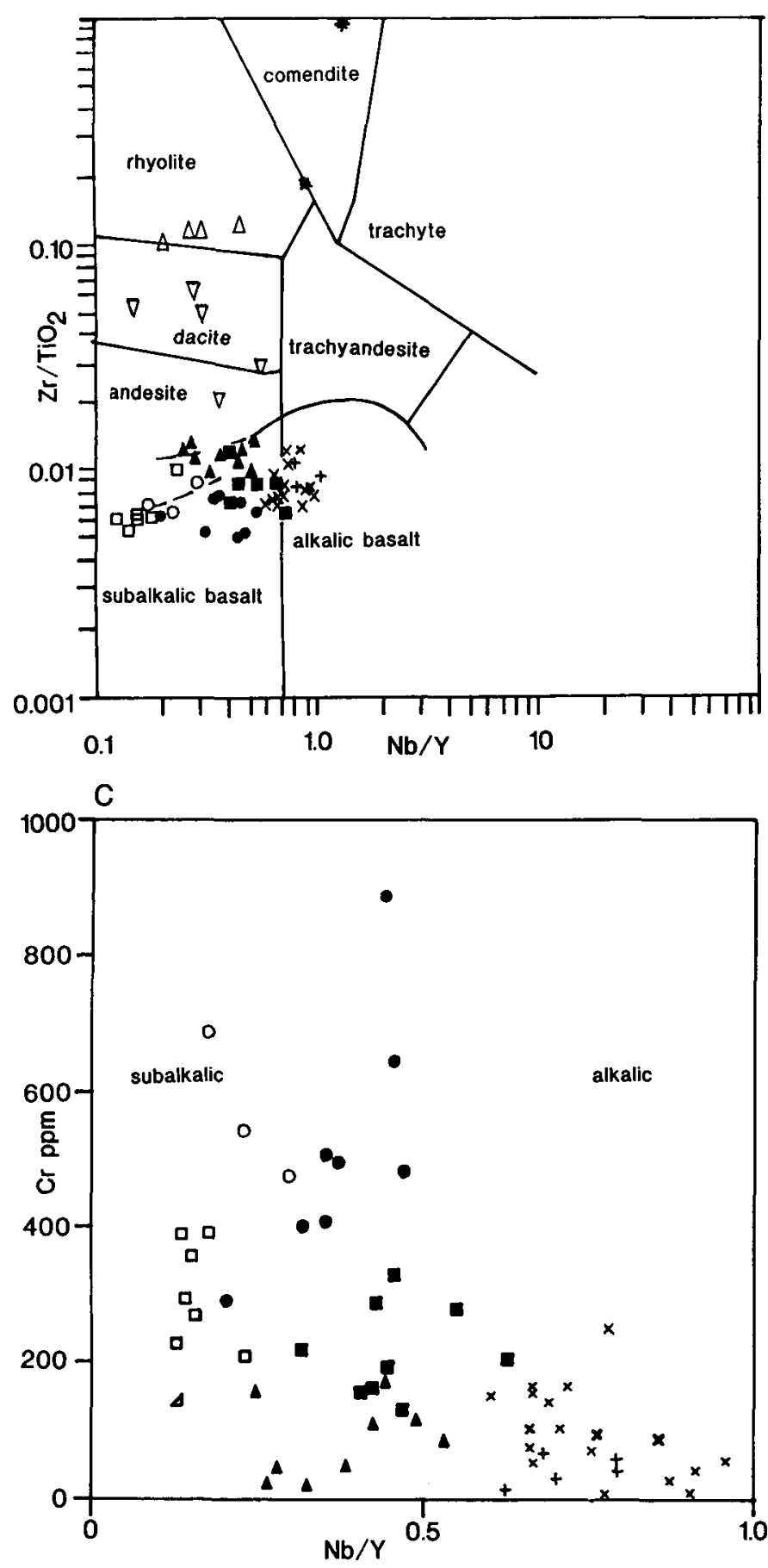

$\Delta \quad$ Felsic volcanic rocks (Dostal's data)

$\nabla$ Felsic volcanic rocks

- Woodstock-Meductic basalts

$x$ Brunswick alkalic basalt

+ Bamford Brook alkalic basalt
B
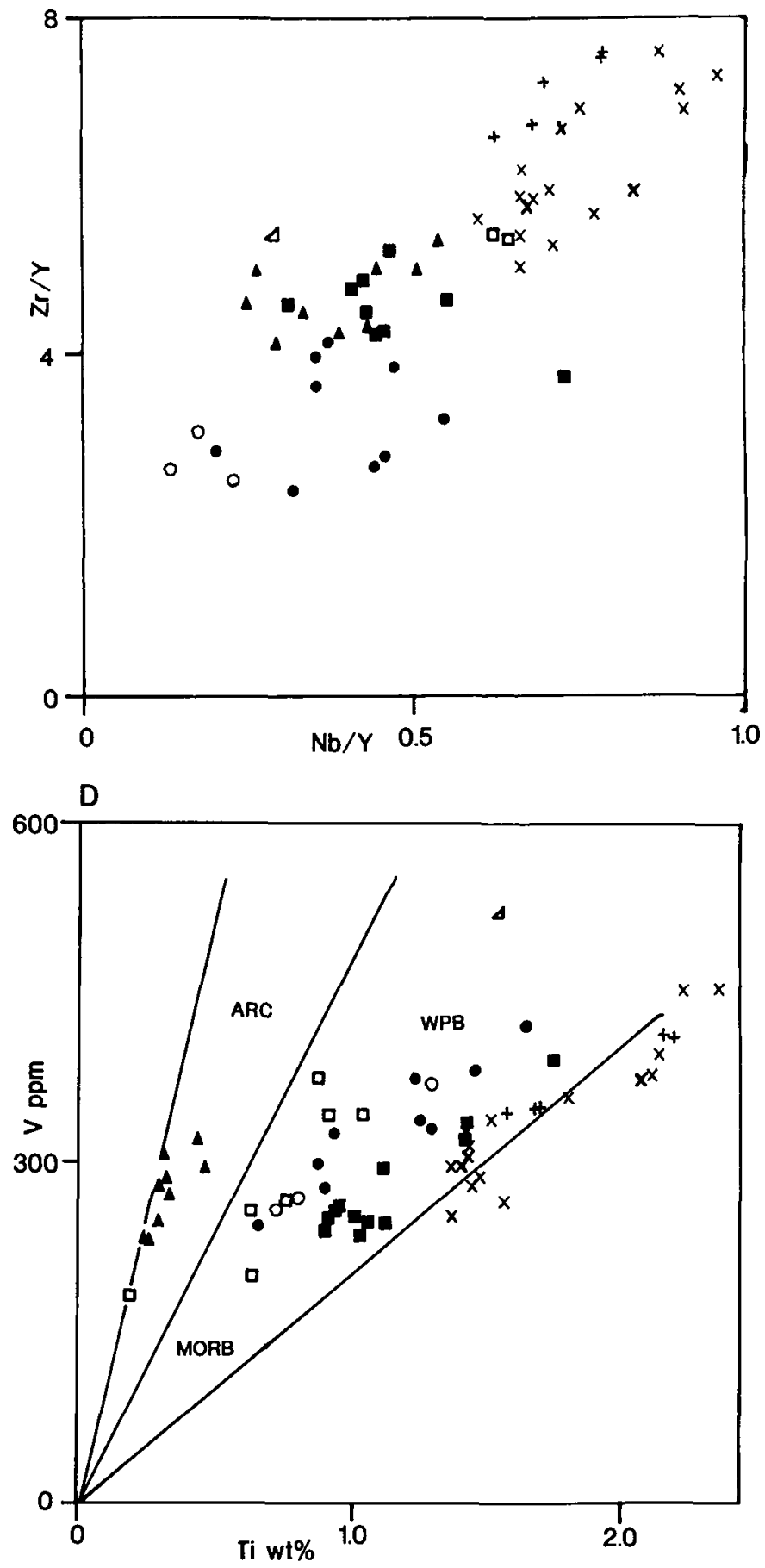

- Trousers Lake striped amphibolite

- Trousers Lake unstriped amphibolite

- Bamford Brook tholeiite

- Forty Mile Brook tholeiite

$\triangle$ Sevogle River tholeiite

* Comendite

Fig. 2. Discriminant diagrams highlighting chemical characteristics of the different volcanic suites in the $\mathrm{CHM}$ and $\mathrm{SMH}$. (A) $\mathrm{Zr} / \mathrm{TiO}{ }_{2}$ $\mathrm{Nb} / \mathrm{Y}$, after Winchester and Floyd (1977). The felsic volcanics plotted include data from the CMH, from south of Danforth, Maine, and data cited in Dostal (1990). (B) $\mathrm{Zr} / \mathrm{Y}-\mathrm{Nb} / \mathrm{Y}$ diagram, plotting basic rocks only. (C) $\mathrm{Cr}-\mathrm{Nb} / \mathrm{Y}$ diagram. (D) Ti-V diagram, after Shervais (1982). WPB - Within-Plate Basalt; MORB - Mid-Ocean Ridge Basalt. 
have $\mathrm{Nb} / \mathrm{Y}$ averaging 0.8 (Table 1 ), thus chemically resembling the Brunswick alkalic basalt suite in the northern Miramichi Highlands (van Staal et al., 1991). They are compared here with Brunswick alkalic basalts sampled near Peabody Lake and in areas E and SE of Heath Steele Mines (Tables 2, 3, Figs. 1,2c). They are confined to the eastern belt of mafic rocks and the eastern margin of the western belt (Fig. 1). Felsic rocks analysed by Fyffe et al. (1988) are chemically similar to those previously sampled (van Staal et al., 1991) in the northern Miramichi Highlands, ranging from dacite to rhyolite in composition. However, one sample (WS 647, Table 1), collected near the South Renous River in the

Table 2. New analyses from east and south of Heath Steele Mines.

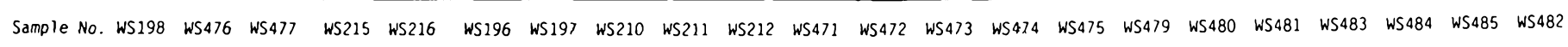

\begin{tabular}{|c|c|c|c|}
\hline $\begin{array}{c}\text { Forty Mile Brook } \\
\text { tholeiite }\end{array}$ & & Brunswick alkalic basalt & Comendite \\
\hline Heath Steele area & Peabody Lake & Heath Steele area & \\
\hline
\end{tabular}

$\%$

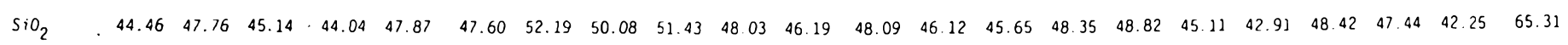

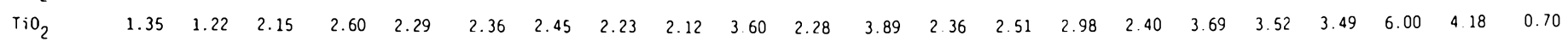

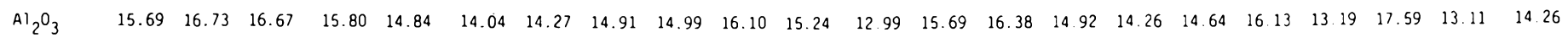

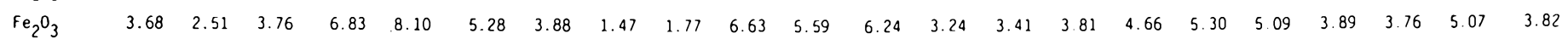

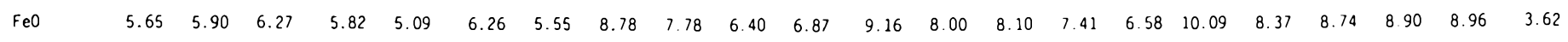

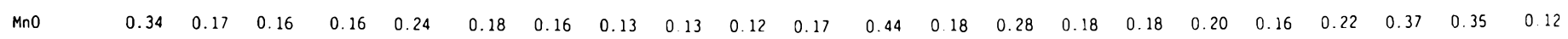

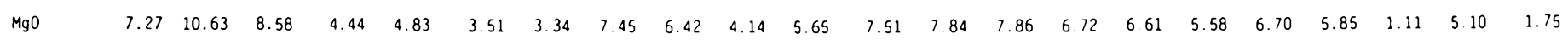

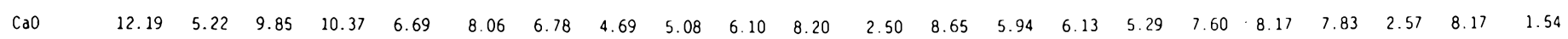

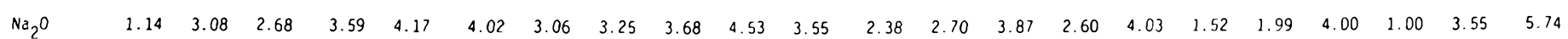

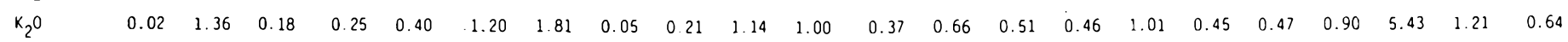

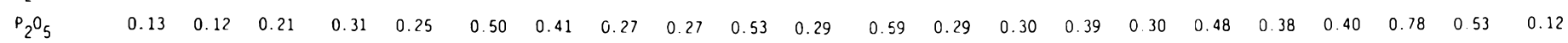

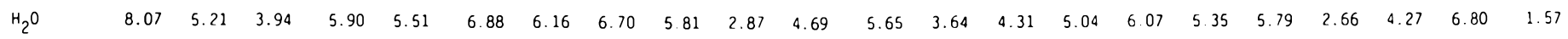

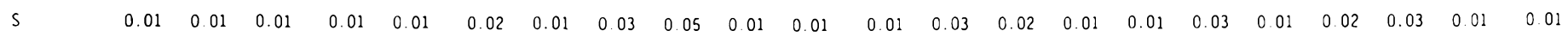

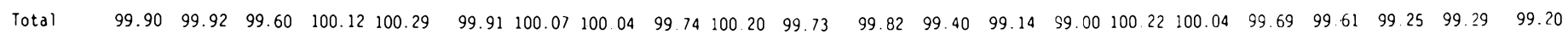

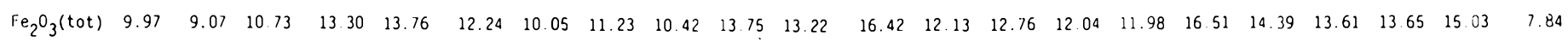

ppm

\begin{tabular}{|c|c|c|c|c|c|c|c|c|c|c|c|c|c|c|c|c|c|c|c|c|c|}
\hline Ba & 15 & 341 & 80 & 60 & 118 & 201 & 170 & 6 & 87 & 189 & 201 & 263 & 539 & 391 & 55 & 494 & 129 & 166 & 288 & 889 & 244 \\
\hline $\mathrm{Cl}$ & 0 & 53 & 93 & 0 & 0 & 0 & 0 & 0 & 0 & 0 & 115 & 96 & 57 & 38 & 100 & 74 & 110 & 73 & 72 & 50 & 73 \\
\hline $\mathrm{Cr}$ & 543 & 475 & 682 & 153 & 149 & 165 & 166 & 107 & 105 & 96 & 73 & 0 & 139 & 101 & 251 & 52 & 3 & 38 & 24 & 70 & 51 \\
\hline Cu & 46 & 14 & 57 & 39 & 55 & 40 & 37 & 30 & 31 & 34 & 49 & 29 & 55 & 53 & 42 & 44 & 33 & 62 & 57 & 43 & 40 \\
\hline Ga & 13 & 17 & 20 & 30 & 25 & 21 & 15 & 24 & 20 & 18 & 22 & 27 & 18 & 21 & 26 & 21 & 23 & 21 & 25 & 38 & 26 \\
\hline No & 8 & 6 & 9 & 22 & 17 & 30 & 28 & 31 & 31 & 39 & 20 & 38 & 20 & 22 & 32 & 24 & 38 & 32 & 28 & 50 & 35 \\
\hline $\mathrm{Ni}$ & 178 & 120 & 237 & 87 & 60 & 71 & 66 & 65 & 50 & 37 & 60 & 25 & 90 & 81 & 119 & 41 & 30 & 49 & 24 & 48 & 45 \\
\hline $\mathrm{Pb}$ & 11 & 18 & 33 & 10 & 17 & 14 & 12 & 28 & 17 & 16 & 15 & 18 & 15 & 11 & 13 & 14 & 15 & 14 & 13 & 68 & 16 \\
\hline $\mathrm{RD}$ & 2 & 41 & 9 & 7 & 13 & 34 & 58 & 2 & 2 & 29 & 22 & 20 & 17 & 14 & 19 & 24 & 14 & 14 & 21 & 129 & 32 \\
\hline $\mathrm{Sr}$ & 225 & 168 & 237 & 259 & 285 & 132 & 176 & 144 & 231 & 266 & 182 & 159 & 337 & 352 & 221 & 98 & 303 & 404 & 168 & 63 & 260 \\
\hline Th & 0 & 0 & 4 & 6 & 2 & 3 & 2 & 5 & 8 & 4 & 7 & 7 & 3 & 5 & 3 & 3 & 7 & 2 & 6 & 8 & 12 \\
\hline v & 269 & 259 & 370 & 267 & 252 & 322 & 286 & 300 & 297 & 352 & 294 & 451 & 315 & 356 & 357 & 278 & 452 & 396 & 376 & 661 & 452 \\
\hline Y & 34 & 20 & 49 & 33 & 28 & 45 & 39 & 46 & 40 & 46 & 30 & 49 & 29 & 31 & 41 & 25 & 42 & 35 & 32 & 66 & 52 \\
\hline $2 n$ & 81 & 71 & 83 & 103 & 92 & 92 & 90 & 101 & 132 & 115 & 107 & 158 & 105 & 113 & 110 & 82 & 150 & 121 & 126 & 197 & 149 \\
\hline $2 r$ & 86 & 108 & 152 & 178 & $15 ?$ & 226 & 207 & 265 & 273 & 271 & 176 & 410 & 169 & 184 & 233 & 182 & 299 & $24 !$ & 241 & 455 & 321 \\
\hline
\end{tabular}

Rare-Earth elements

$\begin{array}{rrrrrrrrrrrrrrrrrrrrrrr}\text { La } & 0 & 0 & 0 & 7 & 35 & 11 & 18 & 34 & 9 & 18 & 8 & 29 & 9 & 0 & 11 & 8 & 9 & 15 & 20 & 27 & 19 & 50 \\ \mathrm{Ce} & 5 & 36 & 18 & 16 & 77 & 19 & 31 & 114 & 71 & 41 & 30 & 68 & 22 & 32 & 58 & 29 & 54 & 69 & 38 & 77 & 60 & 171 \\ \text { No } & 15 & 5 & 9 & 33 & 43 & 29 & 38 & 36 & 44 & 24 & 26 & 50 & 18 & 29 & 43 & 21 & 48 & 46 & 37 & 57 & 40 & 73\end{array}$


Table 3. Selected metavolcanic suites in the Miramichi Highlands. New Brunswick and Maine

\begin{tabular}{|c|c|c|c|c|c|c|c|c|c|c|c|c|c|c|c|c|c|c|c|c|c|c|c|}
\hline & \multicolumn{2}{|c|}{$\begin{array}{c}\text { Bamford Brook } \\
\text { tholeite }\end{array}$} & \multicolumn{2}{|c|}{$\begin{array}{l}\text { Forty Mile T } \\
\text { Brook } \\
\text { tholeite }\end{array}$} & \multicolumn{2}{|c|}{$\begin{array}{l}\text { Trousers Lake T } \\
\text { amphibolite } \\
\text { (striped) }\end{array}$} & \multicolumn{2}{|c|}{$\begin{array}{l}\text { Trousers Lake } \\
\text { amphibolite } \\
\text { (unstriped) }\end{array}$} & \multicolumn{2}{|c|}{$\begin{array}{l}\text { Clearwater } \\
\text { Brook } \\
\text { gabbro }\end{array}$} & \multicolumn{2}{|c|}{$\begin{array}{l}\text { Otter } \\
\text { Brook } \\
\text { tholeiite }\end{array}$} & \multicolumn{2}{|c|}{$\begin{array}{c}\text { Bamford Brook } \\
\text { alkalic } \\
\text { Dasalt }\end{array}$} & \multicolumn{2}{|c|}{$\begin{array}{l}\text { Brunswick } \\
\text { alkalic } \\
\text { basalt }\end{array}$} & \multirow{2}{*}{$\begin{array}{c}\text { Sevogle } \\
\text { River } \\
\text { basalt } \\
x\end{array}$} & \multicolumn{2}{|c|}{$\begin{array}{l}\text { Woodstock } \\
\text { Meductic } \\
\text { basalt }\end{array}$} & \multicolumn{2}{|c|}{$\begin{array}{l}\text { Woodstock } \\
\text { Meductic } \\
\text { felsics }\end{array}$} & \multicolumn{2}{|c|}{$\begin{array}{l}\text { Danforth } \\
\text { félsic } \\
\text { volcanics }\end{array}$} \\
\hline & $x$ & $s$ & $x$ & $s$ & $x$ & s & $x$ & $s$ & $x$ & $s$ & $x$ & $s$ & $x$ & $s$ & $x$ & $s$ & & $x$ & $s$ & $x$ & $s$ & $x$ & $s$ \\
\hline$\%$ & & & & & & & & & & & & & & & & & & & & & & & \\
\hline $\mathrm{SiO}_{2}$ & 6 & 62 & .79 & 74 & 75 & 2.34 & .28 & 3.06 & 2.95 & 2.91 & 49.27 & 3.46 & 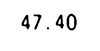 & 1.67 & 5 & 2.66 & 8 & 50.22 & 1.64 & 75.21 & 3.16 & 70.34 & 7.01 \\
\hline $\mathrm{TiO}_{2}$ & & .52 & 1.57 & .50 & 20 & 0.46 & 1.80 & 0.43 & 1.61 & 0.07 & 2.43 & 0.78 & 3.05 & 0.45 & 3.06 & 0.99 & 2.57 & 0.57 & 0.12 & 0.12 & 0.02 & 0.61 & 0.36 \\
\hline $\mathrm{Al}_{2} \mathrm{O}_{3}$ & .24 & 0.60 & 16.36 & .58 & $3 \quad 15.32$ & 1.04 & 15.58 & 0.63 & 6.27 & 0.17 & 14.40 & 1.12 & 14.88 & 1.71 & 14.95 & 1.22 & 14.63 & 17.51 & 1.12 & 13.36 & .59 & 13.94 & 3.11 \\
\hline $\mathrm{Fe}_{2} \mathrm{O}_{3}$ & 319 & 1.91 & 3.32 & 0.70 & 1.97 & 1.34 & 1.53 & 0.20 & 1.93 & 0.04 & 4.19 & 2.32 & 2.68 & 0.44 & 4.67 & 1.71 & 7.75 & - & - & - & - & 1.62 & - \\
\hline $\mathrm{FeO}$ & 6.69 & 1.59 & 5.94 & 0.31 & 8.55 & 1.51 & 8.58 & 1.13 & 6.20 & 0.04 & 7.67 & 2.01 & 8.56 & 0.80 & 7.60 & 1.42 & 6.59 & - & - & _- & - & 3.43 & 1.76 \\
\hline MnO & 5 & 0.30 & 0.24 & 0.14 & 0.20 & 0.03 & 0.19 & 0.04 & 0.15 & 0.01 & 0.21 & 0.06 & 0.29 & 0.09 & 0.21 & 0.09 & 0.23 & 0.16 & 0.02 & 0.27 & 0.02 & 0.14 & 0.08 \\
\hline MgO & 7.19 & 1.54 & 8.83 & 1.69 & 7.66 & 2.14 & 6.69 & 1.06 & 5.84 & 0.68 & 5.78 & 1.33 & 5.89 & 0.38 & 5.59 & 1.81 & 6.80 & 5.98 & 0.82 & 2.16 & 0.63 & 1.03 & 0.41 \\
\hline $\mathrm{CaO}$ & 8.30 & 1.49 & 9.08 & 3.55 & 11.28 & 1.75 & 8.77 & 2.80 & 9.06 & 1.08 & 6.12 & 2.32 & 8.61 & 1.51 & 6.60 & .2 .06 & 5.60 & 9.05 & 2.15 & 0.12 & 0.07 & 0.91 & 0.69 \\
\hline $\mathrm{Na}_{2} \mathrm{O}$ & 4.17 & 1.54 & 2.30 & 1.02 & 2.60 & 0.50 & 2.63 & 0.95 & 3.72 & 0.54 & 4.19 & 1.13 & 3.47 & 0.57 & 3.19 & 0.98 & 3.65 & 3.03 & 1.28 & 3.54 & 1.41 & 1.58 & 1.38 \\
\hline $\mathrm{K}_{2} \mathrm{O}$ & 0.68 & 0.62 & 0.52 & 0.73 & 36 & 0.36 & 7 & 0.63 & 0.81 & 0.05 & 4 & 0 & 8 & 0 & 0.97 & 1.20 & 0 & 1.31 & 0.83 & 1.81 & 1.08 & 3.02 & 0.90 \\
\hline $\mathrm{P}_{2} \mathrm{O}_{5}$ & 0.22 & 0.08 & 0.15 & 0.05 & 0.10 & 0.05 & 0.24 & 0.08 & 0.30 & 0.03 & 0.32 & 0.12 & 0.59 & 0.40 & 0.40 & 0.14 & 0.21 & 0.16 & 0.04 & 0.05 & 0.01 & 0.12 & 0.05 \\
\hline $\mathrm{H}_{2} \mathrm{O}$ & 3.14 & 2.08 & 5.74 & 2.12 & 0.96 & 0.41 & 1.62 & 0.98 & 1.45 & 0.40 & 4.55 & 1.79 & 2.72 & 2.00 & 5.25 & 1.25 & 7.10 & 3.30 & 0.65 & 1.85 & 0.67 & 3.23 & 0.68 \\
\hline$S$ & 0.01 & 0.004 & $4 \quad 0.01$ & 0.00 & 0.03 & 0.01 & 0.02 & 0.01 & 0.01 & 0 & 0.02 & 0.02 & 0.04 & 0.02 & 0.02 & 0.01 & 0.01 & - & 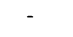 & - & - & 0.02 & 0.02 \\
\hline
\end{tabular}

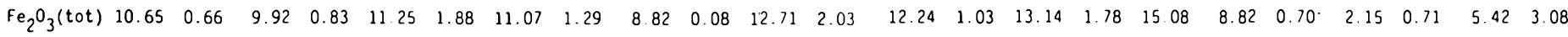

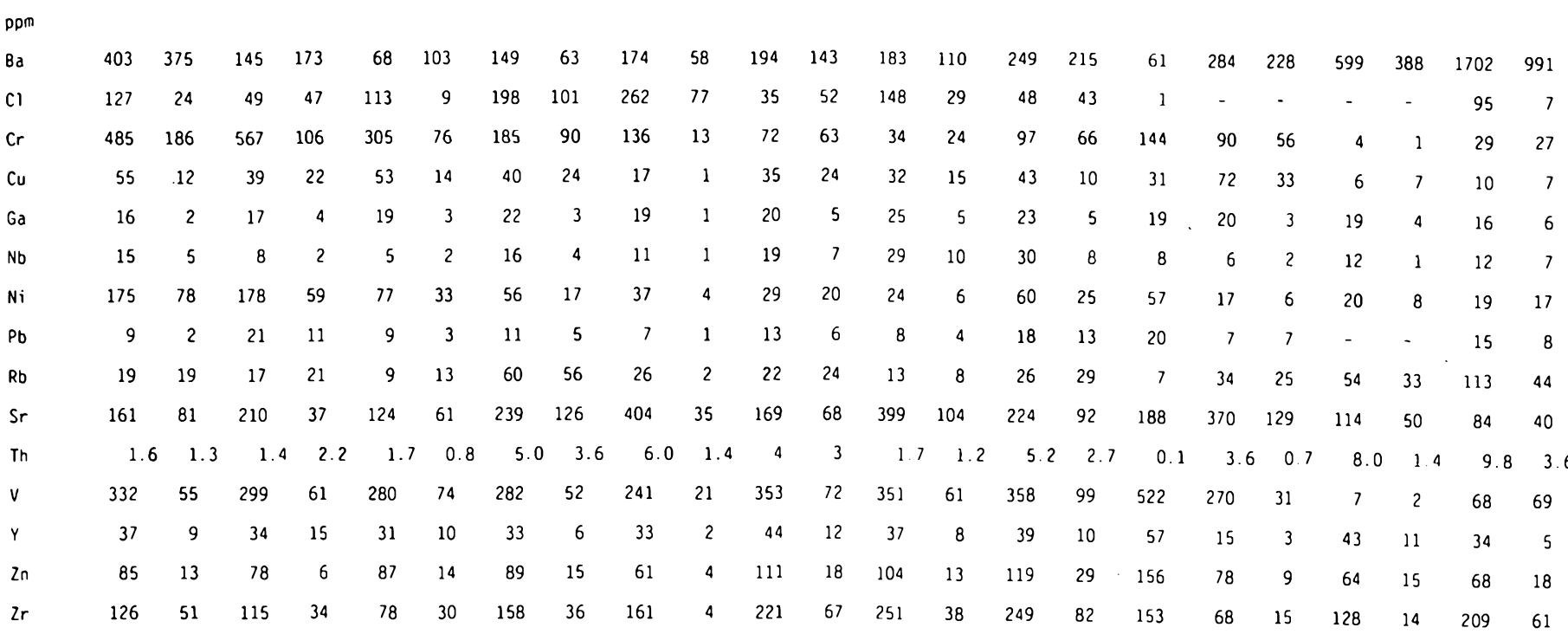

Rare-earth elements

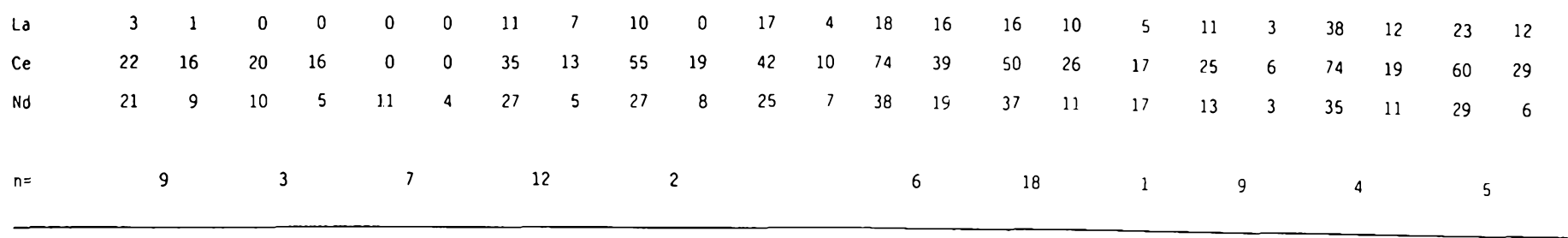

Notes: $x$ - mean; $s$ - standard deviation; $n$ - number of samples

Bamford Brook area, but associated with bimodal felsic and tholeiitic mafic volcanic rocks, is a comendite similar to those associated with the Brunswick alkalic basalt suite in the northern Miramichi Highlands.
In the Trousers Lake area, Fyffe et al. (1988) divided the mafic rocks into two distinct groups (striped and unstriped amphibolites) on the basis of their field appearance. They also found that the $\mathrm{Zr} / \mathrm{Y}, \mathrm{Nb} / \mathrm{Y}$ and HFSE of the striped 
amphibolites is characteristically lower than in the unstriped amphibolites, which probably represent more evolved basalts (Fig. 2a,b,c). Seven additional samples were analysed from the Trousers Lake area for this study (Fig. 1, Table 1), including two samples from the Clearwater Brook gabbro, which had not been previously analysed. The amphibolite results are comparable with those obtained by Fyffe et al. (1988), and the Clearwater Brook gabbro is shown to be chemically akin to unstriped amphibolites. Comparison with the northern Miramichi Highlands shows that the unstriped amphibolites chemically resemble the Otter Brook tholeiites (Tables 1, 3).

The chemistry of the Trousers Lake amphibolites may be compared with that of metabasalts in the Bamford Brook area and the area east of Heath Steele Mines. Compared to the Trousers Lake amphibolites, the Bamford Brook tholeiites are more primitive and contain generally lower $\mathrm{Zr} / \mathrm{Y}$ and higher $\mathrm{Cr}$ and $\mathrm{Ni}$ with $\mathrm{Cr}$ ranging up to $882 \mathrm{ppm}$. (Fig. 2c). A single, extensively altered and weathered specimen of tholeiitic metabasalt from the Sevogle area (Fig. 1, Table 3) consistently plots away from the other metabasalts (Fig. 2b,c,d), but this chemical distinction may not be genuine, as in such an altered sample compositional change affecting even the less mobile elements may have occurred. All these suites plot in the Within-Plate Basalt field on a Ti-V diagram (Shervais, 1982), in contrast to the Woodstock-Meductic basalts (Dostal, 1990) which are characterised by lower $\mathrm{TiO}_{2}$ contents and plot separately in the arc field (Fig. 2d).

When plotted on a multi-element spider diagram (Pearce, 1983) all the tholeiitic basalt suites emerge as relatively enriched (Fig. 3), with profiles comparable to those of basaltic suites in the Tetagouche Group of the northern Miramichi Highlands. Although the Trousers Lake striped amphibolites have somewhat lower HFSE than the other mafic suites, the differences are not large. These differences and relative enrichment of LILE may owe more to metasomatic changes than original composition and are not considered significant.

\section{Discussion}

The reappraisal of the striped amphibolites of the Trousers Lake area superficially suggests that they are chemically similar to the Forty Mile Brook tholeiites in the northern Miramichi Highlands, but they differ in having consistently lower HFSE and thus have no exact equivalent in the latter area. The unstriped amphibolites are more comparable with the Otter Brook tholeiites of the northern Miramichi Highlands, suggesting that all the metavolcanic rocks in the central Miramichi Highlands are equivalent to those seen structurally below the blueschist belt in the northern Miramichi Highlands. The Bamford Brook tholeiites resemble the Forty Mile Brook tholeiites of the northern Miramichi Highlands, which also occur SE of Heath Steele Mines. The Bamford Brook alkalic basalts in the eastern central Miramichi Highlands are chemically akin to the Brunswick alkalic basalts of the northern Miramichi Highlands which also crop out southeast of Heath Steele Mines and near Peabody Lake.
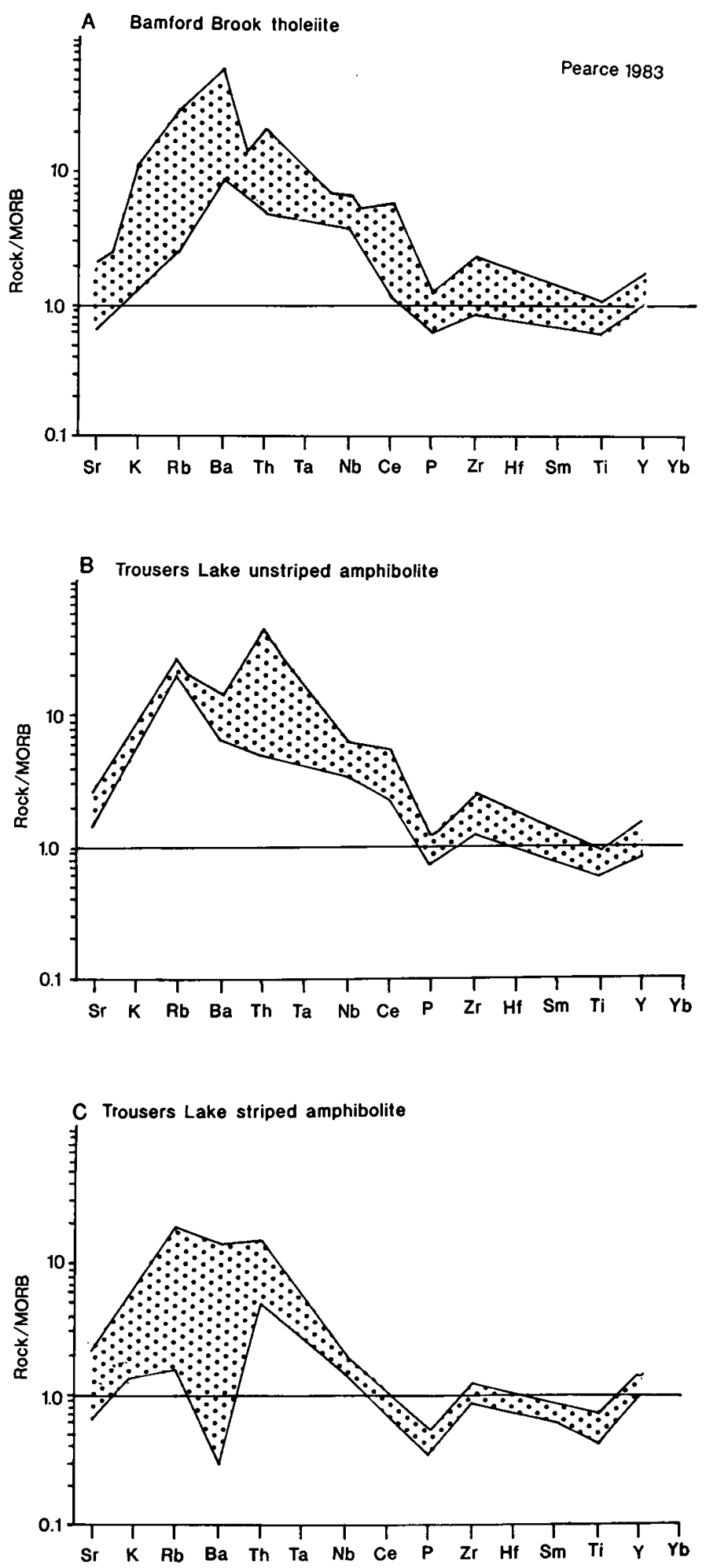

Fig. 3. Multielement spiderdiagrams. Normalization factors (MORB) after Pearce, 1983. (A) Bamford Brook tholeiite. (B) Trousers Lake unstriped amphibolite. (C) Trousers Lake striped amphibolite.

Both the Forty Mile Brook and Brunswick basalt suites, described in the northern Miramichi Highlands by van Staal et al. (1991) therefore probably also extend across much of the central Miramichi Highlands. In the former area the 
structural model proposed by van Staal et al. (1991) shows these volcanic rocks to have been erupted in a thinned Korean-type continental margin setting. HFSE depletion in these rocks, in the absence of supporting field evidence, does not justify the arc setting proposed by Fyffe et al. (1988) and may result instead from crustal contamination.

The occurrence of felsic orthogneisses (Fyffe et al., 1988) and the discovery in 1989 of a comendite among the felsic rocks along the South Renous River in the Bamford Brook area, strengthens links with volcanic rocks in the Tetagouche Group in the northern Miramichi Highlands. There is no chemical indication that the felsic volcanic rocks were erupted in an arc setting.

In contrast, the basaltic and felsic volcanic rocks of the Meductic-Woodstock area in the southern Miramichi Highlands exhibit calc-alkalic affinities (Dostal, 1990) and record arc volcanicity. Their different chemistry and tectonic setting is evident on a Ti-V plot (Fig. 2d). Five calc-alkalic felsic volcanic rocks independently sampled by us in 1989 from the southwestern extremity of the Miramichi Highlands near Danforth in Maine (Fig. 1, Table 4) dominantly comprise variably silicified dacitic rocks (Fig. 2a), which are best linked with the rhyolites of the Meductic-Woodstock suite and support the presence of a remnant volcanic arc in the southern Miramichi Highlands.

Hence, although arc-related volcanics are present in the southern Miramichi Highlands, they do not seem to extend into the central Miramichi Highlands where the tectonic setting of magmatic emplacement was, like that of the northern Miramichi Highlands, a thinned continental margin. These data also support the incorporation of the central Miramichi Highlands rocks into the Tetagouche Group (e.g., Fyffe, 1982). Initial lavas may have acquired higher $\mathrm{Zr} / \mathrm{Y}$ by means of crustal contamination; later magmas (i.e., the Bamford Brook tholeiites), emplaced when the magma pathways were established, tend to be more primitive and have higher $\mathrm{Cr}$ and lower $\mathrm{Zr} / \mathrm{Y}$, thus presenting a more MORB-like character. The amphibolites of the central Miramichi Highlands, therefore, support the model of van Staal et al. (1991) which proposed that during the Middle Ordovician, continental magmatism associated with an extensional regime which split a Lower Ordovician ensialic arc was associated with the formation of a large back-arc basin.

\section{ACKnowledgements}

Funding by NATO for transatlantic travel and subsistence is gratefully acknowledged by JAW. Technical assistance was provided at Keele University by Margaret Aikin and David Emley. This is Geological Survey of Canada Contribution No. 31491.

Dostal, J. 1990. Geochemistry of Ordovician volcanic rocks of the Tetagouche Group of southwestern New Brunswick. Atlantic Geology, 25, pp. 199-209.

FyfFe, L.R. 1982. Geology of Woodstock (Sheet 21J). New Brunswick Department of Natural Resources, Map NR-4.
Table 4. Felsic volcanics from Danforth,

Maine.

\begin{tabular}{|c|c|c|c|c|c|}
\hline & WS631 & พS6 32 & WS6 33 & WS6 34 & WS6 35 \\
\hline \multicolumn{6}{|l|}{8} \\
\hline $\mathrm{SiO}_{2}$ & 76.27 & 61.23 & 77.10 & 72.19 & 64.93 \\
\hline $\mathrm{TiO}_{2}$ & 0.29 & 1.07 & 0.27 & 0.88 & 0.53 \\
\hline $\mathrm{Al}_{2} \mathrm{O}_{3}$ & 11.39 & 17.39 & 12.06 & 11.59 & 17.28 \\
\hline $\mathrm{Fe}_{2} \mathrm{O}_{3}$ & 1.34 & 3.51 & 1.03 & 1.26 & 0.89 \\
\hline $\mathrm{FeO}$ & 1.27 & 6.12 & 2.14 & 4.70 & 2.91 \\
\hline $\mathrm{MnO}$ & 0.08 & 0.28 & 0.10 & 0.14 & 0.08 \\
\hline $\mathrm{MgO}$ & 0.53 & 1.51 & 0.69 & 1.08 & 1.32 \\
\hline $\mathrm{CaO}$ & 1.79 & 0.09 & 0.37 & 1.00 & 1.31 \\
\hline $\mathrm{Na}_{2} \mathrm{O}$ & 0.70 & 0.09 & 2.29 & 1.23 & 3.59 \\
\hline $\mathrm{K}_{2} \mathrm{O}$ & $3: 04$ & 4.38 & 2.17 & 2.25 & 3.24 \\
\hline $\mathrm{P}_{2} \mathrm{O}_{5}$ & 0.06 & 0.11 & 0.09 & 0.14 & 0.19 \\
\hline $\mathrm{H}_{2} \mathrm{O}$ & 3.25 & 4.28 & 1.99 & 3.45 & 3.25 \\
\hline $\mathrm{S}$ & 0.01 & 0.01 & 0.02 & 0.06 & 0.02 \\
\hline Total & 100.02 & 99.07 & 100.32 & 99.97 & 99.54 \\
\hline $\mathrm{Fe}_{2} \mathrm{O}_{3}($ tot $)$ & 2.75 & 10.31 & 3.40 & 6.49 & 4.13 \\
\hline \multicolumn{6}{|l|}{$\mathrm{ppm}$} \\
\hline $\mathrm{Ba}$ & 1138 & 1643 & 1961 & 566 & 3201 \\
\hline $\mathrm{Cl}$ & 106 & 88 & 95 & 89 & 95 \\
\hline $\mathrm{Cr}$ & 8 & 73 & 19 & 38 & 8 \\
\hline $\mathrm{Cu}$ & 1 & 18 & 7 & 16 & 9 \\
\hline $\mathrm{Ga}$ & 12 & 24 & 11 & 12 & 19 \\
\hline $\mathrm{Nb}$ & 5 & 24 & 9 & 11 & 11 \\
\hline $\mathrm{Ni}$ & 6 & 47 & 9 & 22 & 10 \\
\hline $\mathrm{Pb}$ & 4 & 16 & 23 & 11 & 20 \\
\hline $\mathrm{Rb}$ & 96 & 189 & 80 & 88 & 113 \\
\hline $\operatorname{sr}$ & 91 & 38 & 69 & 78 & 146 \\
\hline Th & 5 & 13 & 11 & 7 & 13 \\
\hline $\mathrm{v}$ & 5 & 172 & 21 & 102 & 42 \\
\hline Y & 32 & 42 & 31 & 29 & 35 \\
\hline $\mathrm{Zn}$ & 66 & 99 & 53 & 57 & 65 \\
\hline $\operatorname{zr}$ & 155 & 295 & 164 & 182 & 250 \\
\hline \multicolumn{6}{|c|}{ Rare-earth elements } \\
\hline La & 6 & 37 & 20 & 19 & 33 \\
\hline $\mathrm{Ce}$ & 23 & 104 & 51 & 66 & 56 \\
\hline $\mathrm{Nd}$ & 20 & $\begin{array}{l}33 \\
.\end{array}$ & 32 & 34 & 26 \\
\hline
\end{tabular}


FYFFE, L.R. and Pronk, A.G. 1985. Bedrock and surficial geology - rock and till geochemistry in the Trousers Lake area, Victoria County, New Brunswick. New Brunswick Department of Natural Resources, Mineral Resources Division, Report of Investigation, 20, 74 p.

Fypre, L.R., BARR, S.M., and Bevier, M.L. 1988. Origin and U$\mathrm{Pb}$ geochronology of amphibolite-facies metamorphic rocks, Miramichi Highlands, New Brunswick. Canadian Journal of Earth Sciences, 25, pp. 1674-1686.

IRriNKI, R.R. 1980. Geology of Kennedy Lakes - Little Dungarvon and South Renous rivers region (map areas M-13, M14, M-15 and part of M-16). New Brunswick Department of Natural Resources, Mineral Resources Branch, Map Report 80-2, 39 p.

Pearce, J.A. 1983. Role of the sub-continental lithosphere in magma genesis at active continental margins. In Continental basalts and mantle xenoliths. Edited by C.J. Hawkesworth and M.J. Norry. Shiva Publishing, pp. 230-249.

Rast, N., Kennedy, M.J., and Black wOOd, R.F. 1976. Comparison of some tectonostratigraphic zones in the Appalachians of Newfoundland and New Brunswick. Canadian Joumal of Earth Sciences, 13, pp. 868-875.

Shervais, J.W. 1982. Ti-V plots and the petrogenesis of modern and ophiolitic lavas. Earth and Planetary Science Letters, 59. pp. 101-118.

van Staal, C.R., Winchester, J.A., and Bedard, J.H. 1991. Geochemical variations in Middle Ordovician volcanic rocks of the northern Miramichi Highlands and their tectonic significance. Canadian Journal of Earth Sciences, 28, pp. 1031 1049.

WINCHESTER, J.A. and FLOYD, P.A. 1977. Geochemical discrimination of different magma series and their differentiation products using immobile elements. Chemical Geology, 20, pp. 325-343.
APPENDIX 1: Co-ordinates of sampling localities.

Sample Latitude $\left({ }^{\circ}\right.$ north) Longitude $\left({ }^{0}\right.$ west $)$

$\begin{array}{lll}\text { WS631 } & 45^{\circ} 33^{\prime} 00^{\prime \prime} & 67^{\circ} 53^{\prime} 00^{\prime \prime} \\ \text { WS632 } & 45^{\circ} 32^{\prime} 00^{\prime \prime} & 67^{\circ} 54^{\prime} 00^{\prime \prime} \\ \text { WS633 } & 45^{\circ} 32^{\prime} 00^{\prime \prime} & 67^{\circ} 54^{\prime} 00^{\prime \prime} \\ \text { WS634 } & 45^{\circ} 30^{\prime} 00^{\prime \prime} & 67^{\circ} 54^{\prime} 00^{\prime \prime} \\ \text { WS635 } & 45^{\circ} 30^{\prime} 00^{\prime \prime} & 67^{\circ} 54^{\prime} 00^{\prime \prime} \\ \text { WS636 } & 46^{\circ} 44^{\prime} 25^{\prime \prime} & 66^{\circ} 30^{\prime} 45^{\prime \prime} \\ \text { WS637 } & 46^{\circ} 44^{\prime} 40^{\prime \prime} & 66^{\circ} 31^{\prime} 30^{\prime \prime} \\ \text { WS638 } & 46^{\circ} 45^{\prime} 10^{\prime \prime} & 66^{\circ} 31^{\prime} 50^{\prime \prime} \\ \text { WS639 } & 46^{\circ} 45^{\prime} 10^{\prime \prime} & 66^{\circ} 31^{\prime} 50^{\prime \prime} \\ \text { WS640 } & 46^{\circ} 47^{\prime} 30^{\prime \prime} & 66^{\circ} 27^{\prime} 20^{\prime \prime} \\ \text { WS641 } & 46^{\circ} 47^{\prime} 30^{\prime \prime} & 66^{\circ} 27^{\prime} 20^{\prime \prime} \\ \text { WS642 } & 46^{\circ} 47^{\prime} 30^{\prime \prime} & 66^{\circ} 26^{\prime} 30^{\prime \prime} \\ \text { WS643 } & 46^{\circ} 47^{\prime} 25^{\prime \prime} & 66^{\circ} 26^{\prime} 25^{\prime \prime} \\ \text { WS644 } & 46^{\circ} 47^{\prime} 25^{\prime \prime} & 66^{\circ} 26^{\prime} 40^{\prime \prime} \\ \text { WS645 } & 46^{\circ} 47^{\prime} 25^{\prime \prime} & 66^{\circ} 26^{\prime} 25^{\prime \prime} \\ \text { WS646 } & 46^{\circ} 47^{\prime} 20^{\prime \prime} & 66^{\circ} 27^{\prime} 05^{\prime \prime} \\ \text { WS647 } & 46^{\circ} 47^{\prime} 25^{\prime \prime} & 66^{\circ} 27^{\prime} 20^{\prime \prime} \\ \text { WS648 } & 46^{\circ} 43^{\prime} 20^{\prime \prime} & 66^{\circ} 28^{\prime} 15^{\prime \prime} \\ \text { WS649 } & 46^{\circ} 43^{\prime} 20^{\prime \prime} & 66^{\circ} 28^{\prime} 15^{\prime \prime} \\ \text { WS669 } & 46^{\circ} 51^{\prime} 40^{\prime \prime} & 66^{\circ} 48^{\prime} 20^{\prime \prime} \\ \text { WS670 } & 46^{\circ} 51^{\prime} 35^{\prime \prime} & 66^{\circ} 48^{\prime} 40^{\prime \prime} \\ \text { WS671 } & 46^{\circ} 51^{\prime} 45^{\prime \prime} & 66^{\circ} 51^{\prime} 40^{\prime \prime} \\ \text { WS672 } & 46^{\circ} 52^{\prime} 20^{\prime \prime} & 6^{\circ} 54^{\prime} 00^{\prime \prime} \\ \text { WS673 } & 46^{\circ} 52^{\prime} 20^{\prime \prime} & 66^{\circ} 54^{\prime} 00^{\prime \prime} \\ \text { WS674 } & 46^{\circ} 56^{\prime} 00^{\prime \prime} & 6^{\circ} 54^{\prime} 00^{\prime \prime} \\ \text { WS675 } & 46^{\circ} 56^{\prime} 00^{\prime \prime} & 66^{\circ} 54^{\prime} 00^{\prime \prime}\end{array}$

